\title{
Current Situation Analysis and Countermeasure Research on Rural Primary and Middle School Basic Music Education in Liaoning Province
}

\author{
Xinxin LV \\ College of Education And Sports, Bohai University, Jinzhou, P.R. China \\ jz_Ivxinxin@163.com
}

Keywords: rural primary and middle school; basic education; music education; problem analysis; countermeasure research

\begin{abstract}
Music education is the weak link of basic education in rural primary and secondary school, and has a certain distance between requirement for quality education. This paper accord to "situation analysis - investigate cause - induction reason - propose solution" research ideas, basic theoretical research as the basis, take theoretical research and practical research combined with macro and micro research process of combining, investigate on the basis of the current rural primary and middle school basic music education, summarize existing problems, on this basis and learn from the successful experience of the western developed countries, the corresponding countermeasures from the aspects of music education content, educational effect, teachers, educational facilities, teaching philosophy, etc., has a positive role in promoting and practice value for rural primary and middle school basic music education.
\end{abstract}

\section{Introduction}

Music is humanity's oldest, most universal and infectivity art form, aesthetic education is an important part of the national education policy, music education is one of the main ways to cools aesthetic and quality education. Music education play a positive effect role in students physical and mental development, morally shape, aesthetic ability, etc. Basic education is dual stage of the student's physical and psychological development, through the function of music education, create a healthy and harmonious environment for the growth to student is necessary. This paper researches on basic theory, analysis rural primary and middle school basic music education current situation and point out the existing problems, propose strengthen the measures of rural primary and middle school basic music education, solve the problems of rural primary and middle school basic music education fundamentally, improve the effect of music education. This paper aims to research and explore new theoretical foundation to promote new theories, new methods of rural primary and middle school basic music education reform, solve key issues which affect rural primary and middle school basic music education, provides a theoretical basis to develop music education programs for the education authorities and rural primary and middle school, improve the music education system-building courses and improves music education courses system, promote the overall advancement of rural primary and middle school of music literacy. Theoretically further enrich and complement the existing basic educational theory and method, can provide scientific reference for schools or education authorities in decision-making behavior in practice.

\section{Research Status Review}

With the reform and development of China's basic education, especially with the constantly advancing quality education, basic music education has also made remarkable achievements in recent years, educational administrative departments at all levels of the administration initially establish primary and middle school music education management, consult, teaching and research institutions, have been changed in the past without the specialized agencies and non-state expert management of music education; develop a set of guiding teaching primary and middle school music education regulations and documents, change the music education no laws lax situation, primary and middle schools music courses steady increase, change the music education had a large 
blank area status long time; introduce of learning a variety of foreign famous music pedagogy, teaching has been improved; carry out a series of colorful musical extracurricular school activities, effectively promote the development of the whole school music education [1,2].However, the development of music education is uneven from nationwide perspective. Large cities and developed areas of music teacher preparation and teaching equipment configuration basically put in place, primary and middle schools in these areas are basically able to music education in accordance with the curriculum standards. In the economically underdeveloped areas, especially in the vast rural areas, a serious shortage of music teachers, teaching equipment investment is not enough, the music teaching aren't simply guarantee, this situation has seriously hampered the popularity of basic music education, has been trampled objective ethical bottom line educational equity, is contrary to the spirit that promote quality education in our country currently. Research on our country current basic education in rural primary and middle schools of music focused on learning psychology, music classroom teaching, teaching reform ideas explore, the implementation of the new curriculum and other related fields, analyze and discuss respectively from the music teachers' practical ability, artistic practice ability, teaching ideas, etc aspects, the main concern of the students emotional experience, and daily music instruction and extracurricular educational activities for analysis, pay close attention to subject emotional experience students, and analyzes the daily music instruction and extracurricular teaching activities These findings from the perspective of the theory and practice of music education in primary and middle schools are useful exploration. However, aspects of investigation and analysis is not enough for the specific case commenced, teachers' quality status and the school curriculum and management, Don't give the idea of rural primary and secondary education in line with basic music education and the improvement measures.

\section{Existing Problems}

Through questionnaires and field research methods, master representative problems in rural primary and middle music education exist, and through analysis of survey data, explore the causes of problems. Now mainly summarized as follows [3-5]:

(1) Lack of regular and extra-curricular activities popularity. Carrying out art school extracurricular activities is an important part of school music education, also is the extension of classroom music teaching activities, has a certain meaning and value. But the survey shows that most schools don't have good attention to extra-curricular activities, mainly for the arts festival and student competitions giving surprise, is no plan. Although during the preparation the game, do a vigorous activity, but students get knowledge and improve the quality of their point of view and didn't play a very important role. Only consistently improve extracurricular activities, students can really get knowledge. Proportion of music that Currently the number of schools participating in extra-curricular activities is small, popularity isn't enough. This support relate to school leadership, teacher, parents, there is no truly universal and improve the bonding.

(2) With the objective of education enrollment rate, music education are neglected. Rural primary and middle education reform competent leadership can not keep up with the development trend of education because of inadequate learning, enthusiasm is not high, resulting in the concept of education has been in use the old thinking. Although the country promote the quality of education, but can only stay at the conceptual level, the school only teach, not really do "education", ignore the child beauty education. In the relatively backward economy and culture in rural areas, change the fate of the children by learning, they are bound unconditionally choose college entrance examination. During the transition quality education and examination-oriented education, school leaders are still influenced by the traditional education model, is not deep enough to understand the concept of quality education, lack of knowledge for the new concept of music education, lack of attention, result in music lessons commencement rate that can't guarantee long-term. Enrollment rate is still the focus of attention of school leaders, academic performance is still the main criteria for the evaluation of school leaders. For music education, only care about cultivating music talented students, in order to increase enrollment rate; attach importance to the theatrical festival or game to 
enhance the visibility of the school, ignore the music education to develop the students' aesthetic ability and musical attainments in the true sense.

(3) Students lack of musical quality, aren't high interest in music class. Through the survey found, whether in basic music knowledge and professional skills, quality of students is very low. Even though some students have high quality, but also through extra-curricular system of music education. The ability of students' music quality is low, which directly reflects the lack of the training of students' music ability. Survey results show that a lot of primary school students are full of music, but not like music, which is also a major problem for the development of music teaching in primary and middle schools. The student's indifference to the music class, reflects the many problems that exist in the music teaching. The main reason is that teachers can not meet the students' learning interest in music practice, in the teaching content, teaching methods, teaching methods, lack of innovation, the lack of more suitable for the characteristics of small and middle students music teaching mode.

(4) Lack of music teachers, the quality is poor. Teachers are the fundamental of education, and its level directly influences the teaching level. It is the key to establish a number of sufficient, high quality, excellent service, reasonable structure and stable primary and middle school teachers. It is the key to implement compulsory education and improve the quality of basic education. City party committees at all levels, government and education administration departments attach great importance to the construction of teachers and the construction of teachers' training base, in the ideological and political education, business studies, treatment and improvement, and so do a lot of work. But through the investigation show that the small and middle school teachers still exist many problems, mainly reflect in: overstaffed town school, rural school vacancies phenomenon is serious; assignment system for graduates unfair, in-service teachers equipped with unreasonable; music teachers aren't taken seriously, salary isn't fair; teachers' professional learning atmosphere is weak, less communicate between teachers; weak awareness of scientific research, teaching and scientific research relative lag behind.

\section{Take Countermeasures}

According to the problems of rural primary and middle school music education, use of the basic theory of music education, combine with national policies and regulations, and learn from the experience of the typical developed countries, put forward the countermeasures to strengthen the basic music education is as follows [6-9]:

(1) Rationalize the relationship between the music education and the quality education. Along with the deep research of the relevant theory, people have a clear understanding of the essence of quality education. Quality education is the education which is based on the development of students. First is "development of students", then is followed by "students oriented "."Development" should be the development of all students, the development of a comprehensive and harmonious development, the development of lifelong, the development of personality, lively and vivid development."Student oriented" should include all of the values of the students, the high degree of respect for the ethics of the students, a comprehensive view of the students' behavior, and so on two levels. That is to say, the quality education is for all the students, and pay attention to the personality development, quality education is the comprehensive development and innovation. Quality education should be sincere, help the students to return to the spiritual home, find spiritual home education. In logic, music education is an important part of quality education. Music education is an important way and means to implement quality education. In essence, the ultimate goal of music education and quality education is to promote students' all-round development.

(2) Strengthening the foundation of the music, and steadily improve the artistic quality. Adhere to the ability to adhere to the basic music, abandon the music to learn the general contact. Focus on the cultivation of students a keen sense of hearing feeling ability, kinesthetic response ability and perceptual comprehension ability; basic music knowledge and skill structure optimization, pay attention to music works retain repertoire of reserves and update, attention to appreciate classical 
music works the connotation of experience, basic ability and artistic accomplishment of lifelong development of students participate in music activities required, promote other intelligence development and links. Adhere to the artistic accomplishment, use long-term, comprehensive, find the vision, stimulates the student to participate in music learning deep desire, pay attention to the interests and habits to cultivate; pay attention to independent creation ability, social practice ability and self inquiry desire to develop, cultivate outstanding talent, improve the aesthetic taste and aesthetic quality, to promote students' artistic accomplishment and actively participate in social aesthetic life and meet the needs of the society as an important standard to measure the quality of music education in schools, encouraging the students to participate in extracurricular music activities, will tempering, the cultivation of virtue, comprehension of beauty and taste traditional and social integration, promote the cultivation of innovative talents, reform mode, creating new situation of quality education.

(3) Strengthen the construction of teachers' team, improve the teachers' cultural quality and practical ability. Teachers are the guide of students music education, construct a number of having both ability and political integrity, quality superb and full with the vitality of the faculty becoming the core force of music education in primary and middle school. The education department should integrate all kinds of educational resources, pay attention to the cultivation of the teachers' power, from the reality of the school teachers, through different levels of training and learning to improve the music teachers' personal level and teaching practice ability, and take the teacher's teaching ideas into the music education practice to enhance students' interest and ability to learn music, and promote the healthy development of students' physical and mental health. The main measures are: use of local education resources, train qualified teachers; do a good job in teaching staff training, optimize the teaching staff; take care for music teachers, rational use of talents.

(4) Establish the teaching idea of "inquiry, comprehensive and cooperative". With the launch of the inquiry learning, teacher's role will have changed significantly, and the organizers from the results of the original study "referee", the growth process of "judge" into the process of designers, classroom, learning facilitator, director of teaching, research collaborators. Under this premise, the relationship between teachers and students have changed fundamentally, and the students from the subject to the other party, the teacher also change from the original command to the other party. Teachers and students work together, through music learning achieve spiritual communication, and work together to pursue the united states, create beauty, experience the united states and strive to achieve a comprehensive curriculum reform of education.

(5) Establishment music education network, sharing music education resources. The establishment of music education network, shorten the distance between developed areas and backward areas, shorten the distance between county schools and township level schools, so that all kinds of advanced education and teaching ideas and methods through the network into every corner of rural areas, and promote the development of music education in rural primary and middle schools. The effectiveness and efficiency of the network enhance the effectiveness and efficiency of teacher training, can help teachers to study independently. With the characteristics of the network, the teachers can get the advanced knowledge and advanced information independently to meet the needs of different levels of teachers. Training department and research department cooperate together, set online music education, music database, music paper, teaching case, teaching experience, online classes, etc, support teachers to learn

\section{Conclusion}

Music education is an important part of education, which plays an irreplaceable role in the development of students' comprehensive and harmonious development. Music teaching, as an important course in elementary education, has been through the study and life of the students. Because of lively form, rich connotation, music education is the primary and middle school students' favorite and most willing to accept the teaching content, popular with students. Music teachers as the main teaching of music teaching carry out profound music classroom. To ensure the quality of the classroom, achieve the effect of classroom teaching, complete the teaching task, are 
the duty of every music teacher $[10,11]$. Only in depth study of basic music education in primary and middle school, construct scientific and reasonable teaching mode, the problems in the teaching of basic music can have a correct understanding of the problems, summarize the problems in the teaching practice, ensure the smooth implementation of basic music teaching. Through investigation on the music education in rural primary and middle school, according to the present situation of education, the problems of the music education in rural primary and middle school are summarized, and some suggestions are put forward, based on the further reform and deepening reform of basic music education, it also puts forward some suggestions for the scientific development of music education in rural primary and middle school. Combine with the actual situation, the content of music education, education, teachers, educational facilities, teaching ideas and other research, put forward reasonable reform measures, the development of basic music education in rural areas has a positive role in promoting the role and practical value.

\section{Acknowledgement}

This work is supported by general subject of "the Twelfth Five-year Plan" on educational science of Liaoning province: Current situation analysis and countermeasure research on rural primary and middle school basic music education of Liaoning province, 2014, Approval (JG14CB005).

\section{References}

[1] Z. Y. Fan, J. X. Xie, "The music education based on the diversity of music culture: the present situation and the prospect," Chinese Music, vol. 28, no. 2, pp. 45-49, 2008.

[2] Daphne Rickson, Cunmei Jiang, "The effects of sedative and stimulative music on stress reduction depend on music preference," The Arts in Psychotherap, vol. 40, no. 2, pp. 201-205, 2013.

[3] D. G. Zhao, "Problems and solving strategies of basic music education in China," Big stage, vol. 55, no. 2, pp. 178-180, 2012.

[4 Dimitra Kokotsaki, "Student teachers' conceptions of creativity in the secondary music classroom," Thinking Skills and Creativity, vol. 6, no. 2, pp. 88-93, 2011.

[5] J. J. Gao, "Teaching objectives, contents and methods of the new system of school music education," People’s Music, vol. 65, no. 1, pp. 40-44, 2014.

[6] H. S. Xu, "The current situation and basic strategies of the reform of the basic music education curriculum in China," Journal of the Central Conservatory of Music, vol. 32, no. 4, pp. 106-113, 2011.

[7] Y. J. Li, "Basic education analysis of music teachers' quality and ability training," Journal of Zhoukou normal university, vol. 30, no. 3, pp. 137-139, 2013.

[8] Bilgehan Eren, "Use of Music in Special Education and Application Examples from Turkey Original Research Article," Social and Behavioral Sciences, vol. 116, no. 1, pp. 2593-2597, 2014.

[9] Stefanie Pietsch, Petra Jansen, "Different mental rotation performance in students of music, sport and education," Learning and Individual Differences, vol. 22, no. 1, pp. 159-163, 2012.

[10] Baidu Encyclopedia, "Music Education," http://baike.baidu.com/link?url=1ocFyl41oGJgfl5jHE2sW_QcJg5dfSOPAuOo_mGxIeOm86qe TIvddWNPiJ4Z1X9jE9LeWJL7xwkwH9Kqt8Q7Jq, 2015-8-2.

[11] Y. P. Wang, "The influence of the philosophy of music education on the education of Chinese basic music," Music Space, vol. 63, no. 5, pp. 124-125, 2014. 